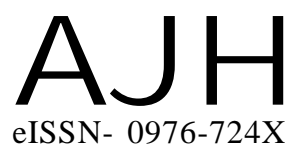

Article history :

Received : 26.02.2014

Revised : 22.09.2014

Accepted : 08.10.2014

\section{Effect of chemical fertilizer and vermicompost on days to flowering, harvesting and maturity of banana (Musa paradisiaca L.) cv. GRAND NAINE}

Members of the Research Forum Associated Authors:

${ }^{1}$ Department of Horticulture, College of Agriculture, Junagadh Agricultural University, JUNAGADH (GUJARAT) INDIA

Author for correspondence : A.M. BUTANI

Department of Horticulture, Junagadh Agricultural University, JUNAGADH (GUJARAT) INDIA

Email : ambutani@jau.in

\section{A.M. BUTANI AND R.S. CHOVATIA ${ }^{1}$}

ABSTRACT : The experiment was carried out at Jambuvadi farm, Department of Horticulture, Junagadh Agricultural University, Junagadh during 2008-09 and 2009-10 for studying the effect of chemical fertilizer and vermicompost on days to flowering, harvesting and maturity of banana (Musa paradisiaca L.) cv. GRAND NAINE. The application of 300-90-200g NPK per plant (full dose of RDF) $\mathrm{F}_{2}$ and $\mathrm{F}_{1}(150-$ 45-100g NPK per plant (half dose of RDF) were found equally effective in promising days to flowering, harvesting and the lowest days to maturity under the treatment 300-90-200g NPK per plant (full dose of RDF) $\left(\mathrm{F}_{2}\right)$ and it was statistically at par with $\mathrm{F}_{1}$ 150-45-100g NPK per plant (half dose of RDF) during both the years as well as pooled results.

KEY WORDS : Banana, Grand Naine, Chemical fertilizer, Vermicompost, Flowering, Maturity

HOW TO CITE THIS ARTICLE : Butani, A.M. and Chovatia, R.S. (2014). Effect of chemical fertilizer and vermicompost on days to flowering, harvesting and maturity of banana (Musa paradisiaca L.) cv. GRAND NAINE. Asian J. Hort., 9(2) :305-308. 